\title{
РОЛЬ ШАРИАТА В СОВРЕМЕННЫХ ПРАВОВЫХ СИСТЕМАХ
}

Аннотация. Исследование посвящено анализу источников уголовного права зарубежных стрна, в том числе мусульманских и их взаимного влияния друг на друга. В рамках уголовного права, существующего за рубежом, источники права являются формой выражения правовых норм. Источниками уголовного права следует считать нормативно-правовые акты, юридические прецеденты, правовые обычаи и договоры. Применительно к источникам уголовного права следует понимать, что исторически сложилось деление права на статутное и прецедентное. В данном контексте исламские государства являются исключением из правил. Результаты исследования получены на основе применения апробированных наукой сравнительно-правового, историко-правового, формально-юридического методов, метода системного и многофакторного анализа. Опыт зарубежных стран показывает, что источником уголовного права может быть не только единый унифицированный акт, например, уголовный кодекс. Важно, чтобы он обладал признаками обязательности, и применялся единообразно ко всем отношениям.Современные уголовные законы ряда исламских государств основаны не только на признаваемых нормах шариата, но и на заимствованных из западноевропейской системы образцах уголовных кодексов.

Ключевые слова: Шариат, мусульманское уголовное право, правовая семья, источники, статутное право, прецедентное право, уголовный кодекс, наказания, кодификация, закон.

Abstract. The author analyzes criminal law sources of foreign countries, including Muslim ones, and their mutual influence. Within foreign criminal law, the sources of law are the forms of legal norms expression. The sources of criminal law usually include statutory acts, legal precedents, legal customs and treaties. With regard to the sources of criminal law, law has been historically divided into statutory law and law of practice. In this context, Muslim countries are the exception to the rule. The research is based on the applied comparative-legal, historical-legal and formal-legal methods, the system method and multivariative analysis. The experience of foreign states shows that the source of criminal law can be presented not only by a unified act, for example the criminal code; but it should be compulsory and should be applied equally to all types of relations. Modern criminal laws of some Muslim countries are based not only on the recognized sharia norms, but also on the criminal codes adopted from the West European legal system. Key words: legal system, sources, statutory law, law of practice, criminal code, penalties, Islamic criminal law, codification, law, sharia.

$\mathrm{C}$ истема и структура источников права зависит от того, в чем же выражаются положения уголовного права - в нормах статутного права, или в конкретных решениях судов. Отметим, что США и Англия принадлежат к странам общего права, одним из главных источников в этих странах является судебный прецедент. А вот в Германии и Франции - странах континентальной правовой семьи - одним из основных источников уголовного права является закон. За долгие годы ученые все же пришли к единому пониманию сущности источника права, как, в частности, и источника уголовного права. Наиболее удобным источником уголовного права на сегодняшний день является именно Уголовный кодекс, в котором обычно выделяют две части - Общую и Особенную. Как правило, Общая часть посвящена освещению понятий и определений, используемых в рамках действующего уголовного законодательства того или иного государства. Особенная часть является более обширной категорией в Уголовном кодексе, поскольку основные составы преступлений, за совершение которых можно привлечь к уголовной ответственности содержатся именно в этой части. Именно те преступные деяния, которые названы в Уголовных кодексах стран мира, и определяют факт посягательства на охраняемые и активно защищаемые государством общественные отношения. Заметим, что Уголовный кодекс - достаточно удобный правовой источник, поскольку в нем в обобщенном виде представлены все составы преступлений, которые законодатель в последующем может свободно корректировать и дополнять. Это целостный кодифицированный акт. Тем не менее, к XXI веку не все государства сходятся во мнении, что Уголовный кодекс - неотъемлемая часть в системе регулирования уголовного права. Например, несмотря на то, что США и Англия являются странами одной правовой семьи, именно в Англии Уголовный кодекс отсутствует. В Англии, в общем-то, и вовсе отсутствует какое-либо подобие унифицированного законодательства, что связано с особенностями развития ее правовой системы. То есть, при установлении преступного деяния законодателю проще полагаться на уже имеющуюся судебную практику и выработанные 
прецеденты как своеобразные, но действующие, источники права.

Говоря о системе наказаний в странах различных правовых семей, можно выделить два принципиальных подхода к построению системы наказаний. Так, во многих странах - бывших колониях Англии - до сих пор отмечается влияние английского права, сохранены простые системы наказаний, избегающие классификации преступных деяний. Например, в Уголовном кодексе Палестины 1936 года, который действует на территории Сектора Газа, существуют следующие виды наказаний: смертная казнь, тюремное заключение, штрафы различной величины, компенсационные выплаты, залог под обязательство, передача под контроль инспектора (ст. 37). При этом важно понимать, что с точки зрения уголовно-правовой доктрины совершенно не обязательно, чтобы источник уголовного права был выражен в форме единого унифицированного акта, как это принято в Германии, Франции или Соединенных Штатах Америки. Важно, чтобы он обладал признаками обязательности, и применялся единообразно ко всем отношениям.

Для системы источников уголовного права, как и для многих других сложных систем, характерна такая черта как «наследственность». Она определяет то, что настоящее и будущее любой системы зависит от прошлого, причем степень такой зависимости от системы может быть любой. Об этой зависимости говорят как о памяти системы [2]. Что собственно и происходит с источниками уголовного права Англии. Наследственность нашла отражение в уголовных законах стран-колоний, которые ранее принадлежали Англии и находились под ее властью.

Развитие систем источников права содержит ряд загадок, на которые довольно часто нельзя ответить однозначно. В частности, почему право, которое формировалось в континентальной Европе, отличалось от системы источников права, которая формировалась в Англии, а впоследствии в ее бывших колониях, способствовало развитию демократического режима, почему тоталитарные режимы, уделяя формальное внимание собственно нормативно-правовым актам, позволяли себе игнорировать их на практике.

Зарождение права в Европе, очевидно, имеет свои корни в первичном или примирительном праве родовых общин. Именно в этот период формируется обычное неписаное право: право родовой общины и племени как предтеча государственного права, межродовое право, как предтеча международного и регионального права. Для него характерно его казуистика, что было следствием юридического решения отдельных конфликтных ситуаций.
Впоследствии, казуистические нормы в отдельных государствах, например, в Англии, сохранились, а в других были заменены более современными правовыми нормами.

Заметим, что уголовные кодексы являются не единственными источниками уголовного права в зарубежных странах. Не менее важными являются и Конституции отдельных государств, которые могут содержать общезначимые нормы принципиального характера. Например, такие нормы имеют место в Конституциях Франции и Германии. В судебной практике США сложился иной подход. Так, суды могут прямо ссылаться на Конституцию как древнейший и самый надежный правовой документ для обоснования своего решения, хотя в Соединенных Штатах Основной Закон принято считать скорее политическим документом, нежели источником уголовного или какого-либо иного права. В Англии суды зачастую находят подтверждение своим решениям и предписаниям в Билле о правах, поскольку писаной Конституции в Англии, как и Уголовного кодекса, тоже нет. Однако Билль о правах признан актом, имеющим конституционное значение.

Следует отметить, что в Англии ранее уже предпринимались действия по кодификации уголовного права. В частности, первая попытка унификации имеющегося уголовного законодательства была сделана в 1833-1849 гг., по ее итогам было подготовлено два законодательных проекта - о преступлениях против личности и о кражах. Ceрьезные работы над кодификацией проводились и позже, так в 1980 г. был создан даже специальный Подкомитет по уголовному права, который опубликовал итоговый вариант проекта английского Уголовного кодекса. Несмотря на то, что Уголовный кодекс, опубликованный в 1989 году, содержал положения общего права и отдельных законов, он как окончательный документ в уголовном праве не прижился [8].

Если говорить о Конституции США, то при назначении уголовного наказания или установлении факта уголовной ответственности придется считаться еще и с конституциями штатов, которые порой содержатся больше действенных норм, чем все американское уголовное законодательство. При этом зачастую случается так, что положения конституций штатов могут устанавливать совершенно противоречивые положения. Так, в §37 ст.1 Конституции штата Орегон имеется запрет на наложении необычных или жестоких наказаний. Смертная казнь при этом не запрещается. В $\S 24$ ст.3 Конституции штата Монтана выработана совершенно иная практика, отменяющая применение смертной казни как одного из тяжелейших уголовных наказаний. Конституция штата Фло- 


\section{Административное и муниципальное право 8 (104) • 2016}

рида запрещает устанавливать неопределенные наказания, а Конституция штата Мичиган ничего подобного не содержит, даже напротив, позволяет законодательному собранию штата применять такое наказание [4].

Кроме того, одними из важнейших источников уголовного права зарубежных стран являются подзаконные акты и специальные уголовные законы. Например, в Англии данные источники востребованы и актуальны. В частности, подзаконные акты в английском уголовном праве издаются парламентом и различными правительственными органами. Преимущества таких актов заключается в том, что они дают возможность быстрее ориентироваться в нормах уголовного права, нежели в существующей судебной практике. При наличии противоречий между законом и подзаконным актом следует избирать ту норму, которая оптимальна к сложившимся правоотношениям, то есть, положения подзаконных актов и законов уравниваются [1]. Специальные уголовные законы обычно являются достаточно неясными и противоречивыми документами. Например, в Англии существует Закон об измене от 1351 г., который в целом не имеет уголовно-правового характера, и действует лишь в той части, что не была отменена Законом об уголовной юстиции [5].

Интересно отметить, что многие мусульманские страны по примеру государств англо-саксонской правовой семьи принимают подобного рода уголовные законы, которые, кроме действующих кодифицированных актов, устанавливают границы ответственности за те или иные преступные деяния.

Говоря об источниках уголовного права стран континентальной семьи, следует упомянуть Францию и Германию как образцовые общепризнанные государства названной семьи. Франция стала первой страной писаного права, поскольку формально устранила из действующего законодательства правовой обычай и судебную практику. Кроме того, базис кодифицированного уголовного права заложила первой именно Франция.

Основными источниками уголовного права Франции следует считать Конституцию 1958 года [6] и Уголовный кодекс Франции 1992 года. Отдельное место в уголовном праве занимают специальные уголовные законы и подзаконные акты, которые издаются исполнительными органами власти. Немаловажная роль отводится и решениям Палаты по уголовным делам Кассационного Суда Франции, хотя по большей части данные решения используются только в роли разъяснений и дополнений к отдельным правовым актам. Несмотря на то, что Франция является страной, в которой закон находится на вершине правовой системы в стро- гом смысле этого слова, судебные решения подчас обходили законодательные нормы и по существу творили свое право. Так продолжалось до тех пор, пока во Франции не был принят Уголовный кодекс, который и стал отправной точкой в становлении нового уголовного законодательства. Хотя судебную практику французских судов нельзя назвать отрицательной, поскольку именно благодаря решениям судов французское уголовное право узнало о существовании института крайней необходимости, которого ранее не существовало, и который в последующем нашел отражение в новом Уголовном кодексе Франции [11].

Не менее важными источниками уголовного права Франции принято считать и ратифицированные международные договоры и соглашения, играющие роль в системе регулирования уголовного права.

Конституцию Франции 1958 года принято считать основополагающим источником уголовного права, прежде всего, потому, что она содержит прямую отсылку к Декларации прав человека и гражданина [3], положения которой были официально провозглашены и признаны еще в 1789 году. Первые нормы, перенесенные в последующем в Основной закон Франции, содержались именно в Декларации. В частности, ст.ст. 5 и 7 предписывают, что каждый волен действовать в рамках закона и что никто не может быть арестован или заключен под стражу, кроме как в случаях, установленных законом. Действующая Французская конституция считает своим прямым источником именно Декларацию, о чем делает прямую отсылку в своей Преамбуле.

По отношению к Конституции Франции, Уголовный кодекс является специализированным и унифицированным правовым актом в области уголовного права. Долгое время уголовное право Франции находилось под влиянием существенно устаревшего Уголовного кодекса 1810 года, где все преступления условно делились на преступления против публичных и частных интересов. Однако эволюция уголовного права затронула существовавшие длительное время уголовно-правовые нормы, что привело к появлению новой иерархии преступных деяний.

Еще одним значимым источником уголовного права Франции является Кодекс военной юстиции от 1982 г., который отдельно регламентирует военные преступления. Некоторые преступления устанавливаются и в уголовных специальных законах, например, в Законе о коммерческих обществах, Законе об азартных играх. Полагаем, что в настоящее время кодификацию уголовного законодательства Франции нельзя считать завершенным.

Источниками уголовного права Германии являются: Конституция ФРГ 1949 года [7], Уго- 
ловный кодекс ФРГ 1998 года [12], специальные федеральные уголовные законы, уголовное законодательство земель, иностранное уголовное законодательство. Особенностью уголовного права ФРГ является то, что оно не полностью кодифицировано. Наряду с Уголовным кодексом существуют и многочисленные некодифицированные уголовно-правовые нормы, содержащиеся в различных законах.

Конституция ФРГ закрепляет ряд уголовноправовых принципов:

- в ст.102 говорится об отмене смертной казни,

- в ст.103 (2) - о том, что деяние подлежит наказанию только в случае, когда его наказуемость была установлена законом до совершения деяния,

- $\quad$ в ст. 103 (3) - о том, что никто не может быть подвергнут многократному наказанию за одно и то же деяние,

- в ст. 104 - о допустимости лишения свободы только на основании уголовного закона и по судебному приговору.

Кодификация УК ФРГ, как об этом говорилось, не является полной. Дополнительным уголовным правом (Nebenstrafrecht) считаются все те не вошедшие в УК законы, которые содержат правовые предписания и ставят определенные действия под угрозу уголовного наказания. Такие уголовно-правовые нормы существуют во многих законах, число которых затрудняются назвать германские правоведы. В среднем их около 1000, из них примерно 30 главные дополнительные законы. Эти законы в большинстве своем содержат нормы, регулирующие не уголовно-правовые, а публично-правовые или гражданско-правовые отношения (например, в области экономического права - § 45 Закона об атомной энергии 1976 г., § 35 Закона о федеральном банке 1957 г.).

Несмотря на то, что неполная кодификация уголовно-правовых норм создает определенную коллизионную систему действующего германского уголовного законодательства, германские юристы полагают, что не существует особых трудностей по применению дополнительных уголовных законов. Тем не менее, страны исламского мира, которые заимствовали образцы уголовных законов названных стран, характеризуются достаточно сложной системой уголовных наказаний. Например, в Иордании совершение преступлений предполагает применение к преступнику следующих наказаний - смертной казни, каторжных работ, тюремного заключения. Совершение проступков влечет следующие виды наказаний - арест, штраф или освобождение под залог, а нарушения могут повлечь краткосрочный арест или незначительный по размерам штраф. Подобный подход свиде- тельствует о существовании в исламских странах, что заимствовали французскую модель системы права, трехмерной системы наказаний, которая группируется не по видам преступлений, а по видам совершенных деяний. Соответственно, к нарушителям и преступникам применяются различные меры уголовного воздействия.

В уголовном законодательстве Ливана и Сирии во внимание при назначении наказания принимаются два основополагающих критерия:

а) тяжесть совершенного правонарушения;

б) характер деяния.

Так, согласно ст. 37-40 Уголовного кодекса Ливана наказания зависит от категорий преступлений, которые подразделяются на общеуголовные и политические, нарушений и проступков. Аналогичная система наказаний установлена и в Уголовном кодексе Сирии 1949 года.

Кроме того, сирийское и ливанское уголовное законодательство содержит указание на возможность применения дополнительных наказаний, среди которых деградация, опубликование приговора, лишение гражданских прав. Дополнительные наказания относятся к категории второстепенных наказаний, которые являются обязательными или допустимыми [9].

В Уголовном кодексе Египта также предусмотрены акцессорные и дополнительные наказания. Акцессорные наказания подлежат обязательному применению, и не включаются в приговор, они направлены на обеспечение исполнения основного наказания и повышение его эффективности. В Уголовном кодексе Омана (ст. 39) основные наказания подразделяются на воспитательные, позорящие и устрашающие. Устрашающими наказаниями является смертная казнь, временное или пожизненное заключение. Позорящие наказания - это краткосрочный арест или штраф [10].

В ряде исламских государств - в Марокко, Алжире, Иордании - существуют категории мер безопасности, которые могут устанавливаться и назначаться взамен основных наказаний. Личные меры безопасности - помещение в психиатрическую больницу, направление алкоголиков и наркоманов в спецбольницы, временное приостановление деятельности юридического лица. Реальные меры безопасности - конфискация имущества, временное или окончательное прекращение деятельности учреждения, освобождение под залог.

Таким образом, страны мусульманского мира, формируя уголовное законодательство, и непосредственно систему наказаний, учитывали не только предписания шариата, но и активно использовали зарубежную практику принятия и разработки уголовных законов. Во внимание принималась практика стран англо-американской 


\section{Административное и муниципальное право 8 (104) 2016}

и континентальной правовой семьи. Германия и Франция являются странами континентального права. Источниками уголовного права Германии являются: Конституция ФРГ 1949 года, Уголовный кодекс ФРГ 1998 года, специальные федеральные уголовные законы, уголовное законодательство земель, иностранное уголовное законодательство. Особенностью уголовного права ФРГ является то, что оно не полностью кодифицировано. Наряду с Уголовным кодексом существуют и многочисленные некодифицированные уголовно-правовые нормы, содержащиеся в различных законах.

Основными источниками уголовного права Франции являются: Конституция Франции 1958 года, УК Франции 1992 года, специальные уголовные законы, подзаконные акты, принимаемые исполнительными органами государственной власти. Большую роль играют и решения Палаты по уголовным делам Кассационного Суда Франции, хотя Франция и считается традиционно страной с континентальной правовой системой, на вершине которой находится закон в строгом смысле этого слова.

Англия и США - страны англо-американского права, где иерархия источников уголовного права является несколько иной.

Так, Англия - это «колыбель» общего права, в той или иной форме реципированного многими странами. На сегодняшний день в Англии не существует Уголовного кодекса и писаной Конституции, хотя на протяжении многих веков предпринимались многоразовые попытки для их создания. Основными источниками уголовного права современной Англии являются судебные прецеденты и статуты (парламентское законодательство). Судебная практика является исторически самым первым источником английского уголовного права.

Американская правовая система возникла на основе английской. Бывшие владения Англии, первые 13 американских колоний, прямо заимствовали принципы общего права. По мере расширения территории США сфера их применения распространялась на новые штаты, несмотря на то, что последние до этого испытывали влияние других европейских правовых систем. Американская правовая система возникла на основе английской. Бывшие владения Англии, первые 13 американских колоний, прямо заимствовали принципы общего права. По мере расширения территории США сфера их применения распространялась на новые штаты, несмотря на то, что последние до этого испытывали влияние других европейских правовых систем. Основными источниками уголовного права США являются Конституция США, Свод законов, конституции штатов, подзаконные акты, издаваемые Президентом, департаментами и ведомствами, а также властями штатов.

Отчасти, некоторые исламские государства использовали английский опыт построения системы наказаний, поскольку признавались длительное время колониями Англии. Другие страны мусульманского мира избрали французскую систему наказаний, которая оказалась гораздо сложнее, и принимала во внимание не только группировку преступных деяний, но и классификацию правонарушений и проступков.

\section{Библиография:}

1. Гук П.А. Судебный прецедент как источник права.-Пенза, 2003.-С. 19.

2. Давыдова М.Л. Нормативно-правовые предписания в российском законодательстве.-Волгоград: Изд-во Волгоград. ун-та, 2001.-С. 48.

3. Декларация прав человека и гражданина от 20 августа 1789 г. / Исторические этюды о Французской революции. Памяти В.М. Далина (К 95-летию со дня рождения) / Пер. с фр. А.В. Чудинова.-М.: ИВИ РАН, 1998.-С. 118-128.

4. Жидков О.А., Лафитский В.И. Соединенные Штаты Америки. Конституция и законодательные акты.-М.: Прогресс, Универс, 1993.-С. 220.

5. Закон Великобритании об уголовной юстиции от 1991 г. [Электронный ресурс].-Режим доступа: http:// constitutions.ru/?p=8115

6. Конституция Французской Республики от 4 октября 1958 г, в редакции от 04 августа 1995 г. / Конституции государств Европейского Союза / под общей редакцией Л.А. Окунькова.-М.: Издательская группа ИНФРА-М - НОРМА, 1997.-С. 665-682.

7. Конституция ФРГ от 23 мая 1949 г. / Федеративная Республика Германия. Конституция и законодательные акты. Пер. с нем. / Под ред. Ю.П. Урьяса.-М.: Прогресс, 1991.-С. 181-234.

8. Мишин А.А. Конституции зарубежных государств, 2-е изд., испр. и доп.-М.: Изд-во БЕК, 1997.-С. 188.

9. Мухаммед-аль-Фадель. Общие принципы уголовного права.-Дамаск, 1978.-С. 377.

10. Низам Тауфик аль-маджали. Уголовное право Иордании - общая часть.-Амман, 2005.-С. 462.

11. Уголовный кодекс Франции от 1992 г., вступил в силу 01 марта 1994 г. / Науч. ред. Л.В. Головко, Н.Е. Крыловой; пер. с фр. и предисл. Н.Е. Крыловой.-СПб.: Юридический центр Пресс, 2002.-650 с.

12. Уголовный кодекс ФРГ / Науч. ред.: Кузнецова Н.Ф., Решетников Ф.М.; Редкол.: Лугку П.Ф., Марченко М.Н., Суханов Е.А.; Пер.: Серебренникова А.В.-М.: Юрид. колледж МГУ, 2000.-202 с 


\section{References (transliterated):}

1. Guk P.A. Sudebnyi pretsedent kak istochnik prava.-Penza, 2003.-S. 19.

2. Davydova M.L. Normativno-pravovye predpisaniya v rossiiskom zakonodatel'stve.-Volgograd: Izd-vo Volgograd. un-ta, 2001.-S. 48

3. Deklaratsiya prav cheloveka i grazhdanina ot 20 avgusta 1789 g. / Istoricheskie etyudy o Frantsuzskoi revolyutsii. Pamyati V.M. Dalina (K 95-letiyu so dnya rozhdeniya) / Per. s fr. A.V. Chudinova.-M.: IVI RAN, 1998.-S. 118-128.

4. Zhidkov O.A., Lafitskii V.I. Soedinennye Shtaty Ameriki. Konstitutsiya i zakonodatel'nye akty.-M.: Progress, Univers, 1993.S. 220.

5. Zakon Velikobritanii ob ugolovnoi yustitsii ot 1991 g. [Elektronnyi resurs].-Rezhim dostupa: http://constitutions. $\mathrm{ru} / \mathrm{p}=8115$

6. Konstitutsiya Frantsuzskoi Respubliki ot 4 oktyabrya 1958 g, v redaktsii ot 04 avgusta 1995 g. / Konstitutsii gosudarstv Evropeiskogo Soyuza / pod obshchei redaktsiei L.A. Okun'kova.-M.: Izdatel'skaya gruppa INFRA-M - NORMA, 1997.S. 665-682.

7. Konstitutsiya FRG ot 23 maya 1949 g. / Federativnaya Respublika Germaniya. Konstitutsiya i zakonodatel'nye akty. Per. s nem. / Pod red. Yu.P. Ur'yasa.-M.: Progress, 1991.-S. 181-234.

8. Mishin A.A. Konstitutsii zarubezhnykh gosudarstv, 2-e izd., ispr. i dop.-M.: Izd-vo BEK, 1997.-S. 188.

9. Mukhammed-al'-Fadel'. Obshchie printsipy ugolovnogo prava.-Damask, 1978.-S. 377.

10. Nizam Taufik al'-madzhali. Ugolovnoe pravo Iordanii - obshchaya chast'.-Amman, 2005.-S. 462.

11. Ugolovnyi kodeks Frantsii ot 1992 g., vstupil v silu 01 marta 1994 g. / Nauch. red. L.V. Golovko, N.E. Krylovoi; per. s fr. i predisl. N.E. Krylovoi.-SPb.: Yuridicheskii tsentr Press, 2002.-650 s.

12. Ugolovnyi kodeks FRG / Nauch. red.: Kuznetsova N.F., Reshetnikov F.M.; Redkol.: Lugku P.F., Marchenko M.N., Sukhanov E.A.; Per.: Serebrennikova A.V.-M.: Yurid. kolledzh MGU, 2000.-202 c 